\title{
ANALYSIS OF THE RED CHALK OF HUNSTANTON, ON THE COAST OF NOREOLK.
}

By R. Calvert Clapham, Esq.

During one of the excursions of the late meeting of the British Association at Cambridge, the red chalk of Hunstanton was examined, and as I am not aware of its having been previously analysed, I obtained a specimen to analyse.

The bed of red chalk is about $3 \frac{1}{2}$ feet thick, and runs along the coast, distinctly seen for soine miles. It rests immediately upon the Greensand, and above lies a bed of white chalk, varying in thickness from 25 feet downwards.

Professor Phillips, of Oxford, informs me that this bed of red chalk has been traced from Speeton, in Yorkshire, to Spilsby, in Lincoinshire, and reappears at Hunstanton, in Norfolk.

It contains many fossils, chiefly of the White Chalk, and also fossils of the Greensand and Gault.

It is an interesting question to consider what is the cause of colour in the red chalk. Professor Phillips thinks that it is derived from decomposed glauconite or decomposed augite (both of which contain protoxide of iron and magnesia). It may also be caused by decomposed iron pyrites, as it will be observed it contains a trace of sulphate of lime.

At Speeton it is in some places a soft red clay, and is used to colour bricks and rough pottery.

The following is the analysis:-

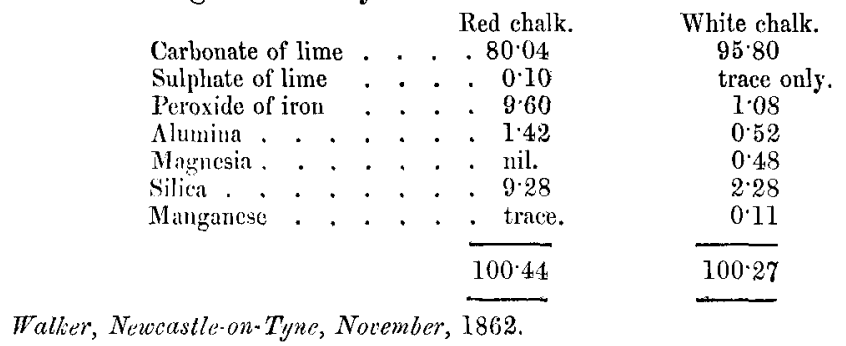

\section{CORRESPONDENCE.}

\section{Ages of Mineral Veins.}

SIR,-Upon reading your report upon Mr. Moore's paper on the " $\mathrm{Pa}$ læontology of Mineral Veins, etc.," before the British Association, a circumstance bearing upon the question occurred to my recollection, which I would have mentioned had I been present in the Section at the time the paper was brought forward. Mr. Moore shows that lead veins in the 